\title{
In Vitro Regeneration of Tea (Camellia sinensis (L). O. Kuntze) By Somatic Embryogenesis from Immature Cotyledon Tissues ${ }^{\#}$
}

\author{
Emine Yurteri $^{1, a, *}$, Mücahit Salih Can ${ }^{1, b}$, Fatih Seyis $^{1, c}$, Haydar Kuplemez ${ }^{1, d}$ \\ ${ }^{1}$ Field Crops Department, Faculty of Agriculture, Recep Tayyip Erdogan University, 53100 Rize, Turkey \\ *Corresponding author
}

\begin{tabular}{|c|c|}
\hline A R T I C L E I N F O & A B S T R A C T \\
\hline $\begin{array}{l}{ }^{\#} \text { This study was presented as an online } \\
\text { presentation at the } 2^{\text {nd }} \text { International } \\
\text { Journal of Agriculture - Food Science } \\
\text { and Technology (TURJAF 2021) } \\
\text { Gazimağusa/Cyprus } \\
\text { Research Article } \\
\text { Received : 02/12/2021 } \\
\text { Accepted : } 31 / 12 / 2021 \\
\text { Keywords: } \\
\text { Tea } \\
\text { Breeding } \\
\text { Exploitation of heterozygosity } \\
\text { Tissue Culture } \\
\text { Genetic variation. }\end{array}$ & $\begin{array}{l}\text { Tea (Camellia sinensis) is the world's most popular beverage plant, as well as an important } \\
\text { plantation crop with high commercial value. It has been maintained for centuries through } \\
\text { conventional vegetative propagation. Tea clonal propagation in vitro has the advantage of producing } \\
\text { a large number of elite plants. If an efficient in vitro regeneration technology is available, this } \\
\text { technique could be exploited for selection of tea plants for desired trait. The selected plants could } \\
\text { be later on multiplied through in vitro or ex vitro techniques. The study aimed to induced somatic } \\
\text { embryogenesis from immature embryo explants to genetic variaton. Different concentrations of } \\
\text { phenylboronic acid with benzyladenine and phenylboronic acid with kinetin were tested in } \mathrm{MS} \\
\text { medium with } 30 \mathrm{~g} / \mathrm{L} \text { sucrose and } 8 \mathrm{~g} / \mathrm{L} \text { agar. } \mathrm{MS} \text { medium without any plant growth regulators was } \\
\text { used as control group. Considering the embryo survival rate, } 1.5 \mathrm{mg} / \mathrm{L}^{-1} \text { phenylboronic acid }+1 \\
\text { mg/ } \mathrm{L}^{-1} \text { kinetin produced highest result as } 87.3 \% \text { while lowest was in control group as } 36.7 \% \text {. The } \\
\text { highest plant regeneration rate was found in } 1,5 \mathrm{mg} / \mathrm{L}^{-1} \text { phenylboronic acid }+1 \text { mg/ } \mathrm{L}^{-1} \text { kinetin and } \\
1.5 \mathrm{mg} / \mathrm{L}^{-1} \text { phenylboronic acid }+1 \mathrm{mg} / \mathrm{L}^{-1} \text { benzyladenine medium respectively as } 58.3 \% \text { and } \\
55.6 \% \text {. Kinetin treatment with increasing phenylboronic acid concentrations gave the best results } \\
\text { in terms of somatic embryo survival rate. Also, kinetin treatment produced better results when } \\
\text { compared to benzyladenine concentrations. }\end{array}$ \\
\hline
\end{tabular}

\section{Introduction}

Tea (Camellia sinensis L.) is a perennial, evergreen and cross-pollinated plant that is a member of Theacea family, an oldest non-alcoholic caffeine containing beverage in the world. (Mondal et al., 2004). Tea is widely propagated by seed, which produces a lot of heterogeneity, or by vegetative cuttings, which can't keep up with the need for new plants. Genetic variation in plants can be induced by many tissue culture techniques like callus culture, use of seeds, and zygotic embryos or embryo recue techniques (Bridgen, et al. 2018). These techniques are successfully applied and reported in several plant species and are used to produce plants resistant to biotic and abiotic stresses and demonstrate improved and enhanced yields and better quality of the end products (Brownand Thorpe, 1995).

This not possible using traditional plant breeding techniques (Thorpe, and Harry, 1996). These techniques help to improve plant characteristics in short period of time and help in rapid breeding (Smith, and Drew 1990). Since use of seeds or embryos or callus cultures lead to induction of somaclonal variations and production of heterozygous plants, these are suitable for inducing variations in plants for selection of appropriate and suitable plants (Pasqual, et al. 2014).

These techniques are also desired explants for protoplast fusion to exploit existing genetic diversity or to produce new genetic variabilities in the genome of the plants (Bridgen, et al. 2018).

Once desired variability is catched, the selected plants can be easily propagated through in vitro or ex vitro techniques(Boopathi, et al. 2021). These can be used efficiently and clonally propagated in large numbers for the trade.

The aim of the study was to exploit heterozygosity in immature embryos of the tea embryos through somatic embryogenesis to use the developing plantlets in breeding of tea. 


\section{Materials and Method}

\section{Plant Material}

The fruits harvested froma private Tea plantations in the Pazar district of Rize (Figure 1) next to the Faculty of Agriculture during the fruit setting periods (AugustSeptember) were used as the seed material in the present study (Figure 2a,b).

\section{Surface Sterilization}

The seed material was washed with water for 30 minutes under an open tap and then it was treated in $70 \%$ ethyl alcohol for 3 minutes. Afterwards, it was kept in 1.8 $\%$ natrium hypochlorite for 15 minutes and rinsed 3 times with sterile distilled water for 5 minutes each.

\section{Medium Conditions and Explant}

The cotyledons of the sterilized seeds were removed under sterile conditions under a stereo microscope (Figure 3 ). Then, the embryonic region of the seed was isolated (5 explants per seed) and planted in 30 petri dishes with 5 explants in each petri dish (Ponsamuel, 1996). All cultures were incubated at two different incubation conditions to induce regeneration; First, explants incubated at $26^{\circ} \mathrm{C}, 16$ hours light and 8 hours dark conditions, 3000 lux light source in growth chamber. In second place, explants were exposed to dark condition at $26^{\circ} \mathrm{C}$.

In order to induce regeneration following in vitro media was used:

- Control: MS medium + $30 \mathrm{~g} / \mathrm{L}^{-1}$ sucrose $+\% 0.8$ agar $+\mathrm{pH} 5.0$

- $\mathrm{M} 1=\mathrm{MS}+1 \mathrm{mg} / \mathrm{L}^{-1}$ phenylboronic acid+ $0.5 \mathrm{mg} / \mathrm{L}^{-}$ ${ }^{1}$ benzyladenine $+30 \mathrm{~g} / \mathrm{L}^{-1}$ sucrose $+\% 0.8$ agar $+\mathrm{pH}$ 5.0

- $\mathrm{M} 2: \mathrm{MS}+1 \mathrm{mg} / \mathrm{L}^{-1}$ phenylboronic acid+ $0.5 \mathrm{mg} / \mathrm{L}^{-1}$ Kinetin $+30 \mathrm{~g} / \mathrm{L}^{-1}$ sucrose $+\% 0.8$ agar $+\mathrm{pH} 5.0$

- $\mathrm{M} 3: \mathrm{MS}+1.5 \mathrm{mg} / \mathrm{L}^{-1}$ phenylboronic acid+ $1 \mathrm{mg} / \mathrm{L}^{-}$ ${ }^{1}$ benzyladenine $30 \mathrm{~g} / \mathrm{L}^{-1}$ sucrose $+\% 0.8$ agar $+\mathrm{pH}$ 5.0

- $\mathrm{M} 4: \mathrm{MS}+1.5 \mathrm{mg} / \mathrm{L}^{-1}$ phenylboronic acid+ $1 \mathrm{mg} / \mathrm{L}^{-1}$ Kinetin $30 \mathrm{~g} / \mathrm{L}^{-1}$ sucrose $+\% 0.8$ agar $+\mathrm{pH}$ 5.0.

\section{Statistical analysis}

Statistical analysis was performed using SPSS 26, a statistical software for Windows 10. All values shown in percentage were arcaine transformed before statistical analysis. The means were separated using Duncans multiple range test was used to separate means.

\section{Results and Discussion}

The highest embryo survival rate was observed in M4 medium with $87.3 \%$, followed by M3 medium with $77.6 \%$ (Table 1). The lowest embryo survival rate was found as $36.7 \%$ in control. In plant regeneration rate results, a similar development to embryo survival rates was observed. The highest plant regeneration rates were found in M4 and M3 medium (58.3\% and 55.6\%, respectively). The lowest plant regeneration rates were found as $27.3 \%$ and $36.0 \%$ in control and M1 medium respectively (Table 1, Figure 4).
In terms of embryo survival and plant regeneration rates, kinetin treatment with increasing phenylboronic acid concentration demonstrated better results. Also, kinetin treatments were found to be more efficient when compared with benzyladenine concentrations. These results were in contradiction with a study by Wachira and Ogada (1995). Researchers have reported that embryogenesis capacity decreases with increasing kinetin and BAP concentrations.

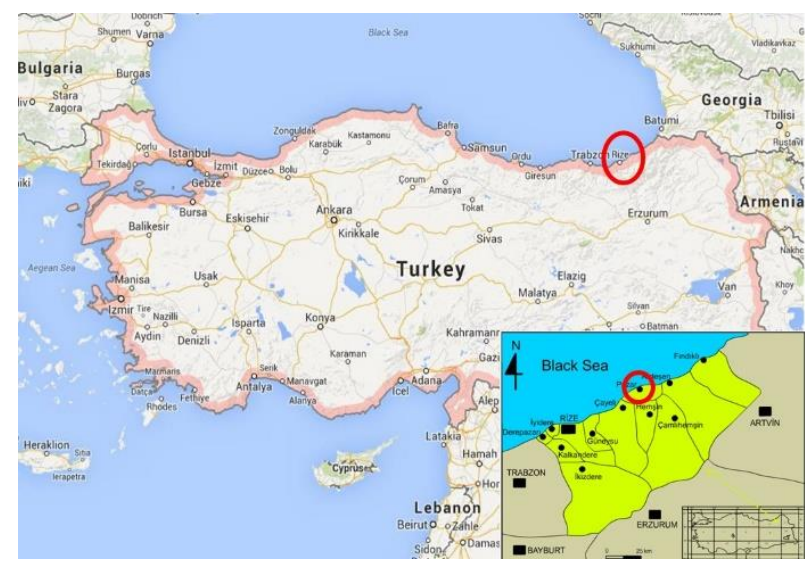

Figure 1. Location where tea fruits/seeds were collected from a private tea farm at Pazar Rize next to the Faculty of Agriculture

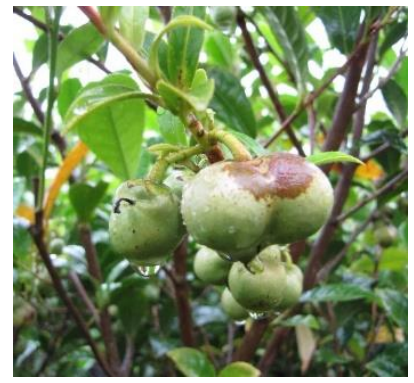

a

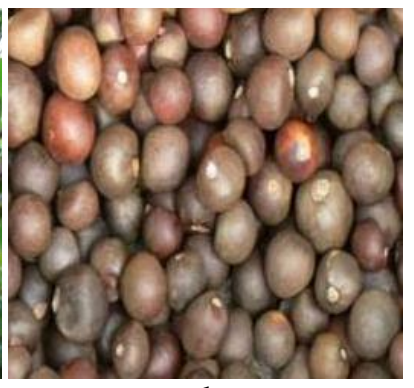

b
Figure 2. a. Camellia sinensis fruits b. Camellia sinensis seeds

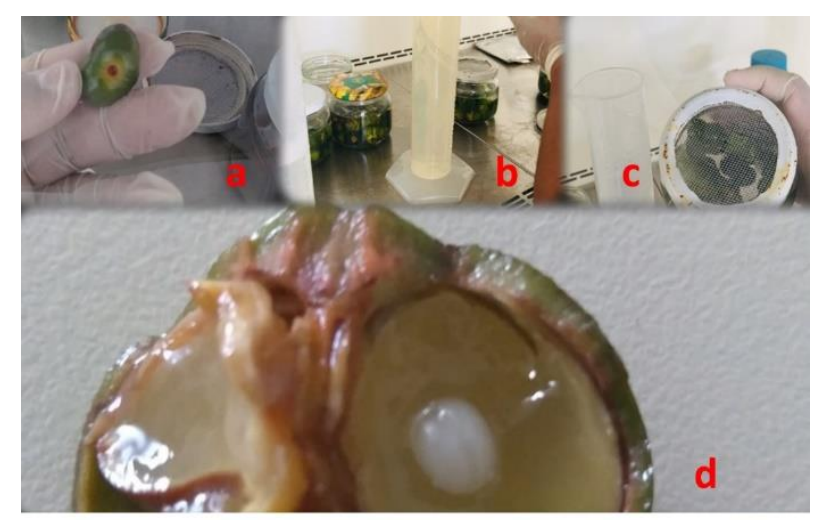

Figure 3. Surface sterilization of Camellia sinensis fruits/seeds(a-c) and dissection of immature embryos (d)

In addition, the results demonstrated differences in terms of explant formation of kinetin treatments in line with the results obtained from the study by Bano et al. (1991). The researchers reported that lower kinetin concentrations produced better results in the formation of somatic embryos, while increased kinetin concentrations caused fragile and non-embryogenic calli. 
Table 1. Regeneration ability and plant regeneration rates of $C$. sinensis embryos cultured in different media

\begin{tabular}{l|ccccc}
\hline Medium & $\begin{array}{c}\text { Number of } \\
\text { Explants }\end{array}$ & $\begin{array}{c}\text { Number of Survived } \\
\text { Embryos }\end{array}$ & $\begin{array}{c}\text { Number of Regenerated } \\
\text { Shoots }\end{array}$ & $\begin{array}{c}\text { Embryo Survival } \\
\text { Rate }(\%)\end{array}$ & $\begin{array}{c}\text { Plant Regeneration } \\
\text { Rate }(\%)\end{array}$ \\
\hline Control & 30 & $11^{\mathrm{e}^{\mathrm{a}}}$ & $3^{\mathrm{e}}$ & $36.7^{\mathrm{e}}$ & $27.3^{\mathrm{d}}$ \\
M1 & 50 & $25^{\mathrm{d}}$ & $9^{\mathrm{d}}$ & $50.0^{\mathrm{d}}$ & $36.0^{\mathrm{c}}$ \\
M2 & 52 & $33^{\mathrm{c}}$ & $13^{\mathrm{c}}$ & $63.5^{\mathrm{c}}$ & $39.4^{\mathrm{c}}$ \\
M3 & 58 & $45^{\mathrm{ab}}$ & $25^{\mathrm{ab}}$ & $77.6^{\mathrm{b}}$ & $55.6^{\mathrm{b}}$ \\
M4 & 55 & $48^{\mathrm{a}}$ & $28^{\mathrm{a}}$ & $87.3^{\mathrm{a}}$ & $58.3^{\mathrm{a}}$ \\
\hline
\end{tabular}

*All values shown in a single column are statistically different using Duncans multiple range test at 0.05 level of significance

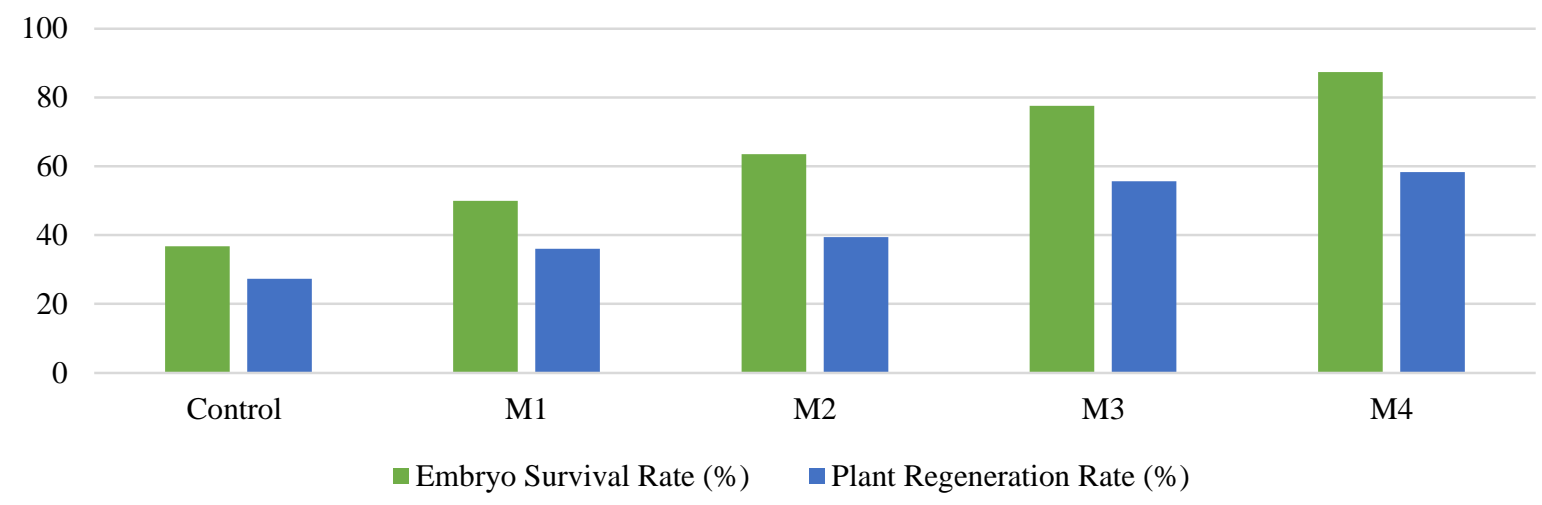

Figure 4. Embryo survival and plant regeneration rates of C. sinensis embryos cultured in different media The developmental stages of explant development after transferring explant to MS medium are given in Figure 5.

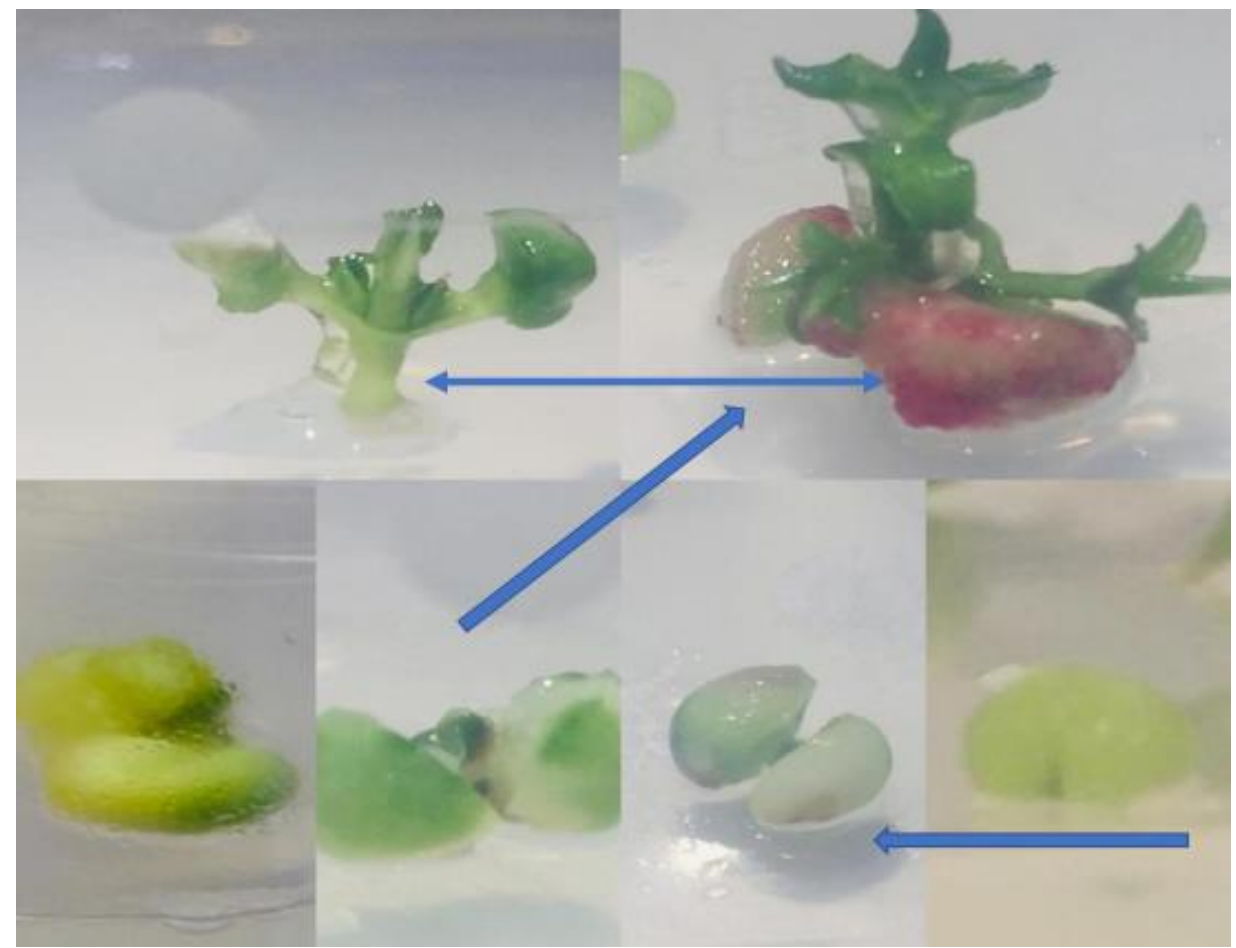

Figure 5. Different stages of explant development after transfer to MS medium from embryo up to shoot development

Shoot organogenesis via callus is relatively difficult in Camellia species, especially from the vegetative parts (Frish and Camper, 1987; Gunasekare and Evans, 2000; Wu et al., 1981). Therefore, somatic embryogenesis could be applied to generate somaclonal variants. Thus in vitro screening is possible in order to select few desirable cultivars. Further, somatic embryos with genotypes of selected elite parents are a potential source in the production of artificial seeds, for germplasm storage, genetic transformation and also for genetic and biochemical studies. Somatic embryogenesis in tissue culture has wide biotechnological applications by virtue of its potential to bring about widespread changes (Lutz et al., 1986; Tulecke, 1987).

As a result of our study, it was determined that increased kinetin concentrations combined with phenylboronic acid induced more embryo survival rate which ensured more plant regeneration rates via somatic embryogenesis from immature cotyledon tissues. Present results indicates that the use of tea cotyledons represents a suitable method in developing tea plants in vitro. 


\section{Conclusion}

Somatic embryos were developed from immatured ovules, which were excised from seed material. In tea plants, seeds are heterozygous in nature and hence further work is necessary to improve the efficiency of somatic embryos and to test the genetic uniformity and quality of embryos produced. Theoretically, somatic embryogenesis with intervening callus stage has genetic variability. Therefore, it provides a new selection method to produce new breeding lines of tea.

\section{Acknowledgement} fundings

This study was supported by TUBITAK 2209A project

\section{References}

Bano Z, Rajaratnam S, Mohanty BD. 1991. Somatic embryogenesis in cotyledon culture of tea (Thea sinensis L.), Journal of Horticultural Sciences, 66: 465-470. doi: 10.1080/00221589.1991.11516175

Boopathi NM, Harshith JD, Santhanakrishnan VP, Raveendran M. 2021. Tissue Culture and Genetic Engineering in Moringa. In: The Moringa Genome, Springer, Cham., 67-83.

Bridgen MP, Van Houtven W, Eeckhaut T. 2018. Plant tissue culture techniques for breeding. In: Ornamental Crops, Springer, Cham., 127-144.

Brown DCW, Thorpe TA. 1995. Crop improvement through tissue culture. World Journal of Microbiology and Biotechnology, 11(4), 409-415

Chen Z, Liao H. 1982. Obtaining plantlet through anther culture of tea plants. Zhongguo Chaye. 4: 6-7.

Dodd WA. 1994. Tissue culture of tea (Camellia sinensis (L.) O. Kuntze), A review. International Journal of Tropical Agriculture, 12:212-247.

Frish CH, Camper ND. 1987. Effect of synthetic auxins on callus induction from tea stem tissue. Plant Cell, Tissue. Org. Cult. 8: 207-213.

Gunasekare MTK, Evans PK 2000. In vitro shoot organogenesis in callus derived from stem tissue of tea (Camellia sinensis L.). Sri Lankan J. Tea. Sci. 66: 35-48.

Jain SM, Newton RJ. 1990. Prospects of biotechnology for tea improvement. Proceedings of the Indian National Science Academy, 6: 441-448.

Lutz JD, Wong JR, Rowe J, Tricoli DM, Lawrence RH, 1986. Somatic embryogenesis for mass cloning of crop plants. pp. 109-116. In: Henke, R.P., Huges, K.W., Constantin, M.J. and Hollanender, A. (Eds). Tissue Culture in Forestry and Agriculture. Plenum press, New York, USA.

Mondal TK, Bhattacharya A, Ahuja PS. 2001. Induction of synchronous secondary somatic embryogenesis in Camellia sinensis (L.) O. Kuntze. Journal of Plant Physiology, 158(7), 945-951. doi: 10.1078/0176-1617-00179
Mondal TK, Bhattacharya A, Laxmikumaran M, Ahuja PS. 2004. Recent advances of tea (Camellia sinensis) biotechnology. Plant Cell, Tissue and Organ Culture, 76(3), 195-254. doi:10.1023/B:TICU.0000009254.87882.71

Mondal TK, Bhattacharya A, Sood A, Ahuja PS. 2000. Factor effecting induction and storage of encapsulated tea (Camellia sinensis L. O.Kuntze) somatic embryos. Tea, 21(2): 92-100.

Mondal TK, Bhattachraya A, Sood A, Ahuja PS. 1999. An efficient protocol for somatic embryogenesis and its use in developing transgenic tea (Camellia sinensis (L) O. Kuntze) for field transfer. In: Altman A, Ziv M \& Izhar S (cds) Plant Biotechnology and In Vitro Biology in 21st Century (pp. 101-104). Kluwer Academic Publishers, Dordrecht, The Netherlands.

Monnier M. 1978. Culture of zygotic embryos. In: Thorpe TA [ed.], Frontiers of plant tissue culture, 227-286. University of Calgary Press, Calgary.

Nadamitsu S, Andoh Y, Kondo K, Segawa M. 1986. Interspecific hybrids between Camellia vietnamensis and C. chrysantha by cotyledon culture. Japanese Journal of Breeding, 36: 309313.

Pasqual M, Soares JD, Rodrigues FA. 2014. Tissue culture applications for the genetic improvement of plants. Biotechnology and Plant Breeding: applications and approaches for developing improved cultivars, 225, 157-199.

Ponsamuel J, Samson NP, Ganeshan PS, Satyaprakash V, Abrahan GC. 1996. Somatic embryogenesis and plant regeneration from the immature cotyledonary tissues of cultivated tea (Camellia sinensis (L.) O. Kuntze). Plant Cell Reports, 16: 210-214.

Raghavan V. 1980. Embryo culture. International Revue of Cytology Suppl. 11B: 209-240.

Raghavan V. 1986. Embryogenesis in angiosperms. A developmental and experimental study. Cambridge University Press, Cambridge, London, New York, New Rochelle, Melbourne, Sydney.

Smith MK, Drew RA. 1990. Current applications of tissue culture in plant propagation and improvement. Functional Plant Biology, 17(3), 267-289.

Thorpe TA, Harry IS. 1996. Application of tissue culture to horticulture. In: III International Symposium on In Vitro Culture and Horticultural Breeding 447, 39-50.

Tulecke, W. (1987). Somatic embryogenesis in woody perennials. pp. 61-91. In: Bonga, J.M. and Durzan, D.J. (Eds). Cell and Tissue Culture in Forestry. vol. 2. Martinus Nijhoff Publisher, Boston.

Wachira F, Ogada J. 1995. In vitro regeneration of Camellia sinensis (L.) O. Kuntze by somatic embryogenesis. Plant Cell Reports, 14(7), 463-466.

Wu CT, Huang W, Chen T, Chen S. 1981. A review on the tissue culture of tea plants and on the utilization of callus derived plantlets. pp. 104-106. In: Proceedings COSTED Symposium on Tissue Culture of Economically Important Plants. Singapore. 